\title{
Communication of Parents to Children in Monitoring Digital Media Use
}

\author{
IKE JUNITA TRIWARDHANI \\ Universitas Islam Bandung, Jl. Taman Sari No. 20, Indonesia \\ Correspondence author: junitatriwardhani@gmail.com
}

\begin{abstract}
People's daily life today can hardly be separated from digital media. Nevertheless, digital media has both positive and negative impacts. The positive impact is digital media makes life easier, but it can also have a negative impact on people's well-being if it is not used properly and out of control. The presence of massive digital media requires wise users. However, it will not be easy for children to do so that they need accompaniment from parents. The form of accompaniment includes effective communication with children by increasing parent's credibility so that children trust their parents and the objective of communication can be achieved. This research is conducted by applying descriptive method. The purpose of this study is to discover how parents communicate with children to help them choose, use, and recognize the benefits and negative impacts of digital media. The results show that parents have an important role in simultaneously accompanying and monitoring their children in using digital media. Parents must be able to communicate in various ways, have the ability to build empathy, own a sense of belonging in children, and allow children to express their thoughts and feelings; those are several considerations for parents in accompanying and monitoring children's digital media use.
\end{abstract}

Keywords: parent to child communication, digital media, monitoring

\section{Introduction}

Digital media is inseparable from everyday life. The rapid development of technology provides various conveniences and attractiveness of digital media so that it becomes an important choice for human life. Communication is made easy since it is not limited by space and time.

But on the other hand, without realizing it, the development of communication technology has negative impacts on human life. Children are the most threatened by continuous exposure to digital media since they were born in this digital era and hardly can live without it.

It is difficult for a child to use digital media wisely without the accompaniment of adults, especially parents. It is afraid that they will only get negative impacts. At their ages, children are often unable to see the benefits of something and fail to recognize something harmful.
The development of increasingly advanced communication media makes it difficult for parents to motivate children to focus on the study because there are so many distractions such as gadgets, television, and social media that are currently booming (Yuniati, Yuningsih and Nurahmawati, 2015).

Parents need to accompany their children in using digital media. The form of parental accompaniment includes effective communication to help children use digital media wisely. The problem raised in this article is the communication skills of parents in accompanying children's digital media use.

The purpose of this paper is to find out how parents communicate in helping children to choose what digital media to use, how to use it, and knowing the benefits and negative impacts of digital media itself. Parents have a role through communication to develop children's abilities naturally, enriched by various experiences and knowledge taught

Received: 2020-09-12, Revised: 2020-10-07, Accepted: 2020-12-22

Print ISSN: 0215-8175; Online ISSN: 2303-2499. DOI: https://doi.org/10.29313/mimbar.v36i2.6654

Accredited Sinta 2 based on the decree No.10/E/KPT/2019 until 2024. Indexed by DOAJ, Sinta, Garuda, Crossreff, Dimensions 
to children in their childhood. Building empathy and a sense of belonging, providing assistance, allowing children to have the right to freedom of expression, and providing assistance/accompaniment are crucial things parents should do.

Negative impacts of using digital media on children emerged due to various factors. Most children do not have the management ability so that they do not know what is beneficial and what is harmful or even dangerous for them. For this reason, parental accompaniment is necessary considering children at their age cannot think about the safety and benefits of things and this would put them in danger.

The communication parents built in accompanying their children on a daily basis should pay attention to child's condition. The ability to empathize developed by parents is very important to understand children as subjects, not objects. Children's knowledge and experiences will be part of the messages that parents develop in providing accompaniment. Mentoring and accompanying can be done through interpersonal communication.

Interpersonal communication established due to the interest of the communicating parties, which also occur in communication between parent and child. Building mutual interest is very important since it determines communication effectiveness. According to the attractiveness theory, communication will develop if the parties involved are interested in each other. The attraction is created because of various factors: closeness, similarity, or even physical (Triwardhani and Chaerowati, 2019).

A child's interest in communicating with parent is important as attractiveness determines the success of communication. Interest can be built in various ways, including by increasing credibility. Children will be interested if the message conveyed is in line with their needs. The closeness in communication is not only physical but also emotional. The closeness in themes being discussed, for example, arise children's curiosity that will attract them into the communication. Children will be interested in knowing more and what is being said. To create such attractiveness, parents should continue to learn, getting to know digital world that is familiar to children. Parents who have more knowledge will be trusted by their children; they are interested in seeking information from their parents.
Children will trust parents whom they think have high credibility; they even can change their opinions with interest just because their parents say so. Generally, the higher the credibility of a person, the more convincing the appeal will be. Parents' credibility can be built through creativity that is attractive to children (Triwardhani, Trigartanti and Putra, 2020)

Parent to child communication should start with the understanding that every child is unique. Children are easily distracted by many things so that one-way communication will make children easily feel bored and reduce their creative thinking. By holding a discussion where both parents and children actively talk and think, effective communication will be established. In essence, since children are mandate or the responsibility of the family, society, and the state, they are always guarded, protected, and have their basic rights fulfilled (Yohana et al., 2018). Good communication between children and parents is a form of direction and protection as a fulfillment of child's rights.

In communicating with children, children need to have the opportunity to express their opinion on the topic being discussed. Two-way communication will make children comfortable and make it easier for parents to convey messages, for example about morals and values, by using a framework of understanding that already known by children (since it is formed already in the family). Discussions for children will be more like chatting or telling stories together which will allow the transfer of experiences among children. Children will find it easier to understand and explore messages that they are familiar with.

Creativity and freedom of creation are important points in building communication with children. The development of creativity cannot be separated from the development of children since childhood is a period where creativity must be allowed to develop. Parents can try to foster creativity in children and change their attitudes and behavior to the better through persuasive communication.

Persuasive communication is not forceful because changes in attitude or behavior come from personal impulses. Building awareness in children is crucial than imposing the will of parents. Thus, persuasive communication is more about creating consistent attitudes and behaviors. Coercive methods tend to make children carry out their parents' wishes out 
of fear, not on their consciousness.

Building a pleasant atmosphere of communication with children should consider their psychological freedom. Directing them subtly will prevent children from fear and compulsion when doing something that is the direction of parents. Subtle ways that touch children's emotions and affections will make them feel like they belong to and enjoy the actions they do. Children will feel comfortable when they know they get accompanied. Accompanying or mentoring doesn't have to be physical. When parents cannot be by the side of children, the accompaniment can be done through the rules being agreed upon, solutions provided by parents through children's experiences, and parent-child communication assisted by digital media.

Communication will not be effective if parents only give instructions and let children understand the message without direction. When a child is carrying out parental directions, the accompaniment will make him/ her feels safe because there is help when he/ she needs it.

In this study, parents consciously communicate with children to foster children's abilities to choose which digital media is appropriate. The communication occurs based on parents' meaning of children's behavior towards digital media. Through an interpretative process, children receive communication messages from parents, which is resulted in children"s behavior in the form of the ability to control themselves against excessive use of digital media.

Persuasive communication accommodates things outside the context of communication but affects the emotional condition of target. Complaints of the child as a communication target must be accommodated so that it does not become an obstacle when he/she wants to do what the source (parent) wants. Parents must be patient with children's requests that are not related to what is being taught. Responding to complaints is part of the accompaniment that will make children feel comfortable; this is also a way to channel children's curiosity.

The principle of openness is important in building interpersonal communication because it will create mutual trust between the two parties. Devito in his book stated that to build openness, both communicators and communicants need to be open with each other. Responses to stimuli must be conveyed honestly. In addition, openness relates to "having" the feelings and thoughts being expressed. Openness also means taking responsibility for the feelings and thoughts being conveyed (DeVito, 2013).

For children to open up, parents need to open up first. Parental openness help children to trust them which in turn supports effective communication between parents and children. Interpersonal communication will be more effective when the atmosphere is equal. Equality here means to accept other parties, or according to the term of Carl Rogers in Devito, it means we give unconditional positive rewards to others (DeVito, 2013).

In addition to openness, the ability to build empathy is also crucial in communication. Effective communication will be established when both the communicator and communicant have mutual empathy, that is, they are able to put themselves in the position of others. For communicants, empathy can help them gain a better understanding so that communication can run effectively. Children who are not merely objects of communication will develop an empathic attitude like that of parents. Empathy is the ability to know what other people are feeling or experiencing, or in other words, the ability to put yourself in someone else's shoes so that we can feel what other people feel.

Empathy for children will help parents to understand how children feel. This condition makes it easier for parents to direct their children more wisely. In building empathy, the process of interpersonal communication between parents and children must be established and continuously fostered to get a strong sense of empathy. The power of empathy will grow continuously along with the commitment of parents to build positive communication with children.

Fostering relationships means establishing relationships and interacting with other people, which in this context are parents and children. Intense and good relationships between parents and children will be more effective than poor relationships (Rahmania and Pamungkas, 2018). If interpersonal communication process is not well-formed, it will be hard to pay attention to and monitoring children in using digital media.

Children sometimes have unstable condition that requires maximum support from parents. Supportiveness in the communication process will make children feel comfortable 
and calm when they have to do something. When children get criticized or rejected, they will feel reluctant, anxious, and afraid to open up. Interpersonal communication and relationships will be effective if there is support among communication actors because open and empathic communication cannot survive in an unsupportive atmosphere.

Supportiveness can reduce defensiveness in communication. Defensiveness is disrespect, dishonesty, and lack of empathy. Being defensive will thwart interpersonal communication because defensive people will busy to protect themselves from "threats" rather than trying to understand other people's messages. Thus, mutual support in interpersonal communication is very important so that each actor of communication can freely express his/her thoughts; and this attitude is very important for children.

Parents' communication with children is largely dependent on the stimuli given. Messages captured and digested by children are not only verbal but also nonverbal such as supportiveness, freedom of expression, etc. Parents who seem to be in a hurry when communicating tend to impose their opinions and do not want to hear any of the children's reasons or opinions. Children will quickly perceive such a message.

When communicating with children, parents need to build a positive attitude. A positive attitude will move people with whom we interact with. Building a positive attitude in communication can be carried out by maintaining a positive attitude yourself and conveying the positive attitude of others. Keeping positive feelings is important to building effective communication and interaction so that the people with whom we interact will have positive feelings too.

The positive feelings both parties have will move these individuals. Being emotionally moved is an important point of transactional analysis and human interaction in general. When we can make people emotionally moved, whether positive or negative, we treat them as human beings. To emotionally move the children, parents can gently touch them, smile at them, and give hugs or verbally show affection to them. Positive attitude is important for effective interaction to create a pleasant communication climate that can support effective communication between parents and children.

Besides positive attitude, equality in communication also bolsters effective communication. Equality means the acceptance of other parties or according to Carl Rogers' terms in Devito, equality demands us to give positive unconditional rewards to others (DeVito, 2013). Equality in the context of parent-child communication is shown by positive appreciation from both parties.

The rapid development of technology makes various information both positive and negative easily accessible by the public. Technological advances do not only affect the wider community, but also children. The results of a survey by the Ministry of Communication and Information Technology (Kominfo) in collaboration with UNICEF entitled Digital Citizenship and Safety stated that 30 million children and adolescents in Indonesia are users of the internet and digital media. The study results published on the official Kominfo website explained the main reasons children and adolescents access the internet: from fulfilling school assignments to just meeting personal needs for socializing or entertainment.

The presence of digital media makes it easier for children to access the internet that has various contents. The online learning system used today makes children more familiar with digital media in their daily lives.

Digital media can be an alternative to innovative and creative learning methods so that they can refresh the learning process. Digital media provides a large space for children to learn because they can not only listening but also carrying out other activities such as observing, practicing and doing presentations (Kurniasih, 2019)

The presence of digital media in education not only changes the way students learn but also changes the way parents educate and convey values to children (Balya, Pratiwi and Prabudi, 2018).

Technological advances that bring about many changes and convenience can become opportunities if they are used intelligently and wisely. These opportunities, when being used optimally, are quite encouraging to increase student motivation which will improve the quality of education (Muhasim, 2017). Digital media can also become a solution for parents in guiding their children to learn.

On the other side, the use of digital media by children can lead to dependency; they can also get into a bad environment 
because of a lack of parental control. Digital media provides easy access to find information, but using it without knowing the rules will cause problems, including getting information from unreliable sources and encountering inappropriate and dangerous content for children (Juditha, 2019). Given this negativity, parents need to extra monitoring the information received by their children so they will not immediately digest it without having proper knowledge about it.

In addition, children may accidentally or even deliberately access various information that driven their interest and curiosity. This situation endangers children as the nation's next-generation and can impact shifting cultural values (Balya, Pratiwi and Prabudi, 2018).

Because of this impact, it is urgent to accompany and monitor children when they use digital media. Parents are required to guide children so that they understand the proper use of digital media. By knowing the rules, children can control themselves in using digital media and minimize its negative impact.

Currently, in addition to good literacy skills and knowledge in the use of digital media for children, parents also have to understand how to condition their children. Parents need to be cautious in facing the digital era, meaning that they must be able to think quickly to prepare their children for the current era. Discipline is an important mechanism in directing children's development (Junida, 2019).

Digital technology should be used for worthwhile things that have an effect on children's development (Rahmawan, Mahameruaji and Janitra, 2020), namely activities of substantial value that use digital media as a means of communication (Putra et al., 2018).

The role of a parent is very important in directing children to wisely use digital media and sort out which things have the most influence on children's lives. Communication between parents and children to monitor technology use is not only done face-toface, but also through other media, such as social media accounts and history of device usage; monitoring children's activities using digital media is also an effective form of communication (Triwardhani et al., 2020).

\section{Research Methodology}

This research uses a case study approach. Robert K. Yin argues that a case study is an empirical inquiry that investigates phenomena in the context of real life. The boundaries between phenomena and context are not visible where multiple sources of evidence are utilized (Yin, 2015). The case study design applied in this research is a single holistic case design.

The case raised in this research is unique, namely digital media phenomenon that many parents complain about because it interferes with children's development. However, there is a group of parents who have the ability to accompanying/monitoring of children's digital media use. Data collection techniques used were interviews, observation, and literature review.

Informants in this study who meet the criteria are parents who have children

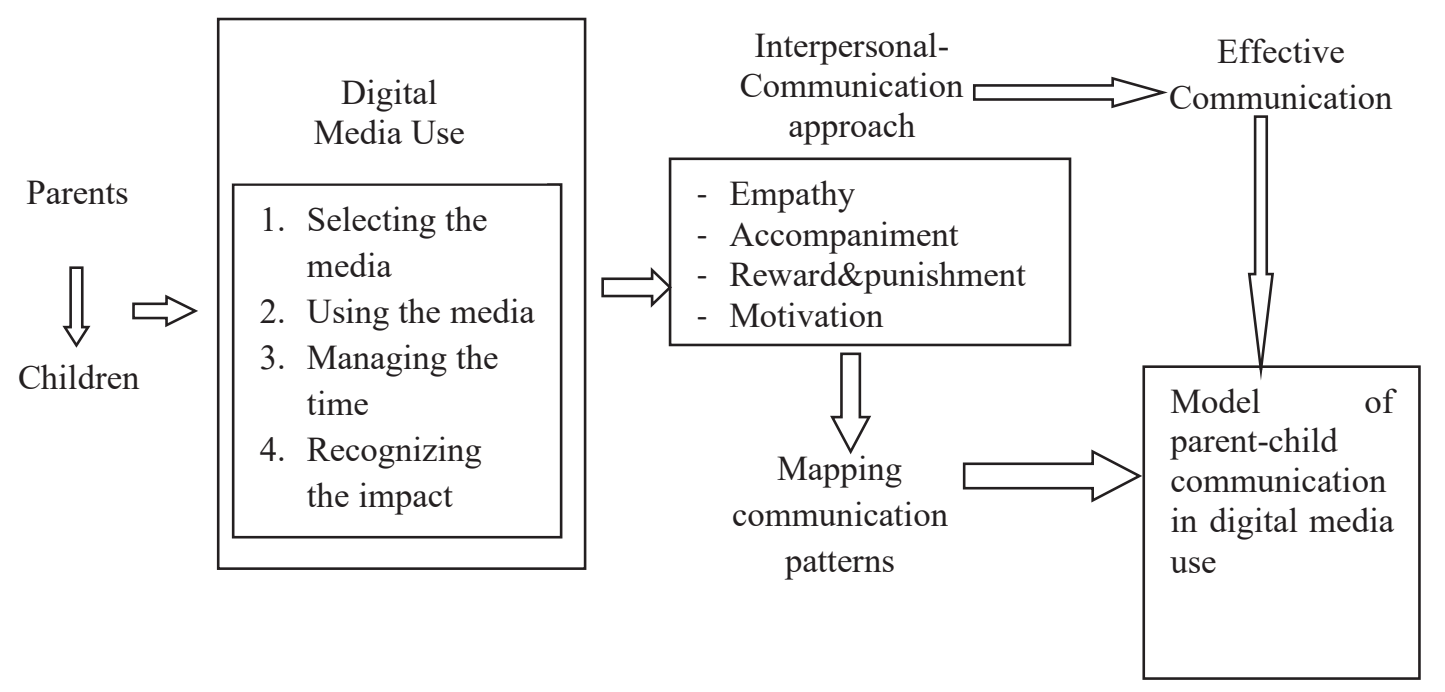

Figure 1. Research Chart 
aged 5 to 10 years old that have used digital media with a minimum education level of undergraduate. Interviews with informants are conducted to explore data about how parents build communication with children in accompanying the use of digital media.

Besides observations and interviews, researchers also collected data through document searches. Schatzman and Strauss emphasized that documents are essential ingredients in qualitative research (Mulyana, 2001). Researchers have carried out documentation studies by looking and digging for documents related to research.

The research steps are mapped in figure 1 while simultaneously guiding the monitoring process more substantively towards the research process and results.

\section{Results and Discussion}

In the era of digitalization, choices on online media are abundant. The rapid development of technology requires education for children to be more innovative (Pransiska, 2013).

Interestingly, digital media which is superior in terms of ease, sophistication, and availability, makes it difficult for children to choose which ones are good, appropriate, and necessary for them. Since children don't have much experience, parents need to accompany children in selecting digital media to use.

The main criterion in selecting media for children is that it has to have benefits, either benefit of education, entertainment, increasing the creativity, having a value in life, providing examples/role model, inspiring and motivating. Digital media being consumed should be able to strengthen spiritual values in education that need to be done in a planned manner and to create an atmosphere that encourages children to continue to develop their values (Setyaningsih et al., 2019)

Digital media consumed by children must be adjusted to their age because oftentimes they watch programs that are not their portion, but since those programs are creatively wrapped up, they are interested in watching them.

Choosing the appropriate digital media for children needs to be done through communication that involves parents and children. Communication is conducted for children to be able to develop values, distinguish good from bad, overcome various problems, and achieve their best (Dewi, Yani and Suhardini, 2015). Parent to child communication must be carried out considering that digital media is extremely broad and provides various information that is sometimes beyond children's' thinking.

\section{Encourage Children to Discuss}

Parent-child communication can take the form of discussion. Having a discussion is the best choice since parents and children can discuss all things related to digital media that are of interest to children. The discussion can be done through interpersonal communication between children and parents. Interpersonal communication has various motives, including building a pleasant atmosphere with the people involved in the communication (Saraih et al., 2019).

To have a pleasant discussion with children, parents need to build credibility that is to broaden their horizons about various digital media options currently available. Parents have to know what kind of digital media needs of their children, be able to choose the media that suits their needs, know what the media content is, and know its impact and long-term benefits. Thus, when the discussion takes place, parents can show children that they can be trusted and can be a reference figure.

Parents who willing to learn will gain knowledge about what digital media that is attractive and suitable for their children and how to make optimal use of digital media. Knowledgeable parents will attract children to make them discussion partner. Conversely, a lack of knowledge will make discussion boring, and children prefer to make decisions based on what they know and want so that the process of controlling through discussion is not successful.

In addition, parents must have extensive knowledge and insight to provide smart input and guide their children. The credibility of parents will make communication process with children more effective (Triwardhani and Gartanti, 2018), where children respect their parents and show a positive attitude (Halim and Azizan, 2017).

\section{Developing Parents-Children Open- ness}

Children's orientation in consuming digital media is more influenced by what trends in their circle of friends. They focus 
on the things they think are fun and ignore the benefits of digital media. This is where parents -armed with knowledge- provide good arguments rather than based on emotion alone to forbid children to waste time on bad digital media. Openness is an important key to discuss with children because, by openness, children trust their parents.

Openness encourages more intense communication, personal closeness, and a desire to convey what is felt. On the contrary, if parents stick to their opinion, close themselves off from the information available, children will respond the same and do something that is not agreed upon behind their parents' back.

Parents can ask children to talk and discuss the positive and negative impacts of using digital media while being given concrete examples, especially those related to their daily lives. Children are given the freedom to express their views and opinions and explore what is being said.

Parents can also communicate about the success and progress of exemplary figures both from home and abroad. Positive and inspiring information that can be accessed through digital media can be an interesting discussion material. Parents should have the capability of managing messages and information in discussions with children, for example, telling them factual things as an introduction to explaining the positive and negative impacts of digital media use.

Information conveyed by parents can be sourced from various incidents happened to someone related to the use of digital media, for example, the bad impact of using digital media continuously in terms of health or bad behavior of children who do not want to do their school tasks and busy playing gadgets instead. Information about negative impact of media must be balanced with positive information. Parents can tell about the achievements of someone who can use digital media correctly. For example, an 8 years old child who can create educational games that can be used by many people, or a child who is successful in running a small business through digital media.

Delivering messages to children can be done using various communication techniques, one of which is storytelling techniques that provide concrete examples, such as comparison between negative effects and positive impacts.

\section{Communication with Children to Choose Proper Digital Media}

The rapid development of technology has made the choices of digital media children can consume are so diverse. Therefore, children need help to wisely and precisely pick the best media for them. Media that can be accessed by children should be able to support their learning and add insight and knowledge.

In choosing digital media, parents should accompany their children considering that children at their age haven't had the capability of choosing things wisely. Effective communication between parents and children is a good form of accompanying and monitoring. Discussion is the right choice so that parents do not impose their will on children and they listen to children's opinions about digital media will be chosen.

The variety of choices makes the challenge of selecting digital media even tougher. One of the effective ways is to communicate with children and choose according to what they need so as parents do not force their will on children. Accompaniment through dialogue and familiarizing the discussion should also followed by sufficient knowledge and insight from parents about digital media.

In order for children to be interested and understand what their parents say, communication must be done in a more interesting and dynamic way, both verbal and non-verbal (P.Pontoh, 2013).

Good credibility of parents will increase children's confidence in what parents say, especially about digital media will be consumed.

Openness is an important key to directing children's choices towards digital media. When children's choices are not appropriate, parents can prohibit it by providing a reasonable explanation. The explanation is conveyed through discussion accompanied by the argumentative ability of the parents equipped with sufficient insight; that way, children will not object if their choices are not agreed by parents.

On the other hand, parents should also listen to children's opinions and broaden their insight so that discussion with children can be fun.

By getting used to communicating effectively and empathizing with children's condition, accompaniment will be a good 
solution to prevent children from choosing bad digital media. The benefits of communication should be felt by individuals involved in communication to get ideal process (Deveci and Ayish, 2018).

Parents are expected to help children choose what digital media to use and why, and what types of media can be accessed, all of which in a discussion that require for their responses. Parents also need to ensure that digital media consumed is suitable for children's needs and is safe. Being close to the world of children is a must for parents so that parents know things related to children's school and hobbies. If children like to play games, parents must ensure that the games they play are age-appropriate and do not contain violence.

\section{Communicating to Accompany Chil- dren in Using Digital Media}

Accompaniment is not only done in choosing digital media, but also in using the media. Parents should tell their children how to access good content, what content or materials can be watched and downloaded, as well as the ethics that must be applied when using digital media. Through accompanying, many things can be taught to children. Communication in the form of discussion or exchange of ideas is an effective way to convey good things to children. One of the important things for this communication to run well is parents who have broad insight.

Digital media often takes up almost all children's time. Even for those who are addicted to games, for example, most of their day is spent playing games. Children find it difficult to control the time they spend playing games, which is very dangerous to their mental and physical health.

This is where parents have to take part as a companion for children to manage their time in using digital media. Children are given a schedule in using digital media so that they know when they can use digital media and for how long. Making a schedule should not be done by parents alone, but together with children so that they have a sense of belonging to adhere to the schedule. Schedules for digital media are usually adjusted to children's load at school so that they have the opportunity to interact with nature and the environment and do not spend much of their time surfing in cyberspace alone.

Once again, children should adhere to the schedule they have made together with their parents. Parents must help children to be disciplined and follow the schedule. Children need to be reminded if they are not disciplined in adhering to a schedule. When children's activities and conditions change, the schedule should also be adjusted to that change. This means that parents must be flexible in scheduling so that children do not feel pressured and are happy to comply with their schedule.

In terms of time management, parents can show their credibility by having complete information about children's daily activities as well as good management skills so that they can help children manage time in using digital media. Parents who pay attention to their children must understand children's busy schedule so that it can be a reference to determine when the proper time for children to use digital media. Discussions with fellow parents who have children of the same age can also be a reference for choosing the right time for children to use digital media. Discipline in implementing a schedule for using digital media is carried out by parents by means of empathic communication to children's condition.

\section{Impact of Digital Media on Children}

Constant use of digital media can make children addicted, which means they lose a lot of time playing and socializing. Not only that, children can also get health problems because they are moving less, physical inactivity, when in fact children at their age should physically active.

As long as digital media provides goodness for children, such as helping them complete school assignments, having educational and scientific values, giving religious values, providing inspiration and motivation, providing entertainment that is not excessive other than just relaxation, stimulating creativity and thinking skills, then digital media considered to be safe and have positive impacts. These things must be taught to children so that they can become media literate from an early age. This is important to prevent them from being addicted to excessive media technology and becoming asocial, or as popular term called it "autistic kid". Excessive use of digital media can make children living in virtual world and forget their real life, even though their real life is the reality they should living on daily basis and they have a lot to learn from this real-life and 
environment. This negative influence of media is oftentimes failed to understand by media digital users; whereas it also has an impact on the users' psychology for they prefer to be alone and busy with their own digital media (Arnus, 2015).

The negative impact of digital media, especially social media, includes the number of cases of kidnapping, fraud initialized from conversations on Facebook, and Twitter that makes parents to be more careful in accompanying children. Most of children do not realize these dangers because they are less alert, careless, and unable to think beyond. Social media is a popular media marked by the number of users and types of social media emerged (Nugraha and Akbar, 2018).

The violence caused by children imitating scenes in digital media, eyestrain, and physical fatigue due to playing games consistently are negative impacts of digital media in general. It is difficult for children to detect and even see the possibility of negative impacts. Therefore, parents need to carry out the accompaniment process by explaining to children about these impacts. Telling stories and showing the phenomena and facts are ways that can be chosen to convince children about the negative impact of digital media. However, explanations cannot be repeated once because children easily forget things and do not pay much attention. Parents should remind them continuously. This negative impact needs to make parents aware of children's digital media use.

Parents should remind these negative impacts to children in various occasions, for example when gathering in the family room, watching television, etc. so that children understand and can take care of themselves. Socialization is also carried out when children are accessing digital media. Any type of media accessed and used as learning material will be discussed and explained; it is not limited to digital media only, but can also discuss the influence of television shows and commercials, etc. This is done with the hope that children can understand the initial phase of learning media literacy. In discussions, children are often asked for their responses and then the answers are explored in everyday life.

In explaining the effect of using digital media on children, parents should open a discussion to see from children's point of view. Let the child ask questions and argue. A detailed explanation will make them understand the impacts that may arise. Children will also build knowledge based on the experiences they have had (Yu, 2009).

All parents have a desire to prevent negative impacts of digital media. However, they often cannot accompany their children all the time. Building intensive communication will be crucial to familiarize children to tell their parents about everything so that their condition can be monitored.

When children have been negatively impacted by digital media, parents should first recognize the types and levels of the negative impacts, then take action. Parents should find out whether children need help from other parties such as psychologists, school officials, etc.; or can it be overcome by yourself, for example, parents help children get rid of their addiction to watching video games as one of children's favorite digital media.

The accompaniment means intensive mentoring that requires great discipline and attention, but children's psychological health must always be prioritized. The negative impact that generally arises is children's inability to manage time when using digital media. They often pass the time limit because they are too busy accessing digital media, let alone playing games. The first step is to remind the children to pay attention to the schedule that has been agreed upon. In addition, accompaniment needs to be carried out when children are accessing digital media, for example by placing digital media facilities such as computers in a place that can be monitored, monitoring children's conditions while using digital media, and paying attention to children's activities (Novrialdy, 2019).

A lot of information unsuitable for children still appears frequently, so that parents should be cautious about it. Parental accompaniment and monitoring is very important because a poor understanding of digital literacy will affect children's psychology (Pratiwi and Pritanova, 2017)

The presence of digital media also has an impact on cultural and lifestyle changes where children easily adopt what they see on digital media (Nurrizka, 2016). Negative impacts occur because children are not able to filter information. Parents need to communicate with children about negative impacts of digital media so that children know various events arise as the results of digital media misuse.

Intensive communication can also 


\begin{tabular}{|c|c|c|c|}
\hline \multicolumn{4}{|c|}{ PARENTS TO CHILDREN COMMUNICATION ON DIGITAL MEDIA USE } \\
\hline $\begin{array}{l}\text { Parents to children } \\
\text { communication in } \\
\text { choosing digital media }\end{array}$ & $\begin{array}{l}\text { Parents to children } \\
\text { communication in helping to } \\
\text { use digital media }\end{array}$ & $\begin{array}{l}\text { Parents to children } \\
\text { communication in managing } \\
\text { time to use digital media }\end{array}$ & $\begin{array}{l}\text { Parents to children } \\
\text { communication in helping } \\
\text { children recognize negative } \\
\text { impact of digital media }\end{array}$ \\
\hline $\begin{array}{l}\text { Choosing suitable media } \\
\text { to use } \\
\text { - Discussion with } \\
\text { children } \\
\text { - Listen to children's } \\
\text { opinion } \\
\text { - Express all opinions } \\
\text { - Convey information }\end{array}$ & $\begin{array}{l}\text { Accompanying children in } \\
\text { using digital media } \\
\text { - Communicating the ethics } \\
\text { in using digital media } \\
\text { - Communicating the proper } \\
\text { - way to access digital media } \\
\text { - Discussing important and } \\
\text { interesting issues }\end{array}$ & $\begin{array}{l}\text { Creating schedules with } \\
\text { children } \\
\text { - Discussing the ideal time to } \\
\text { use digital media } \\
\text { - Reminding children to be } \\
\text { consistent with the time set } \\
\text { - Reward and punishment }\end{array}$ & $\begin{array}{l}\text { Explaining negative impacts } \\
\text { of digital media to children } \\
\text { - Tell cases of violence } \\
\text { occurred on social media } \\
\text { - Tell bad events occurred in } \\
\text { the near environment } \\
\text { - Building children's } \\
\text { awareness of those dangers } \\
\text { above }\end{array}$ \\
\hline 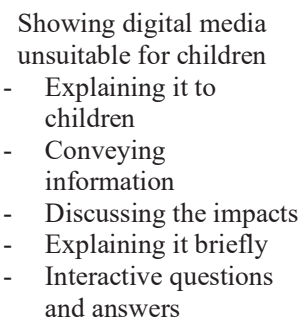 & $\begin{array}{l}\text { Teaching children how to use } \\
\text { digital media } \\
-\quad \text { Discussing with children } \\
-\quad \text { Explaining it to children } \\
\text { - } \quad \text { Communicating how to } \\
\text { use digital media in } \\
\text { accordance with the rules }\end{array}$ & $\begin{array}{l}\text { Provide tolerance for changes } \\
\text { to the schedule has been set } \\
\text { - Communicating children's } \\
\text { daily activies } \\
\text { - Communicating schedule } \\
\text { changes with children } \\
\text { - Communicating schedule } \\
\text { revisions with children }\end{array}$ & $\begin{array}{l}\text { Observing children's behavior } \\
\text { and attitudes regarding the } \\
\text { impact of social media } \\
\text { - Intensive communication } \\
\text { - Observing children's verbal } \\
\text { and non-verbal language } \\
\text { - Listening to childrens' } \\
\text { stories to monitor their } \\
\text { conditions }\end{array}$ \\
\hline
\end{tabular}

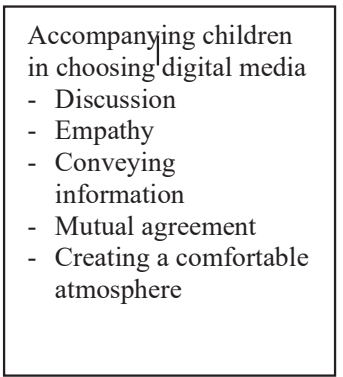

Figure 2. Model of Parent to Child Communication in Using Digital Media

detect if children have been badly affected by digital media or is it just negative symptoms. Parents' prior knowledge will help children get the treatment faster.

\section{Parents-Children Communication Model in Digital Media Use}

From the description above, parentschildren communication model in digital media use can be drawn up as shown in figure 2 .

\section{Conclusions}

Accompanying children in choosing digital media is crucial since children have not been able to determine what is good and what is bad in using digital media. Accompaniment is carried out by means of communication that takes into account the elements of openness and a high sense of empathy for children's condition. Openness will make children trust their parents while providing a comfortable and pleasant atmosphere.

In order for the discussion to be effective, parents must equip themselves with broad skills and insights about digital media. Parents must be able to provide recommendations on which media are suitable for children's consumption, especially those containing elements of education, entertainment, insight, knowledge, inspiration, motivation, and creativity.

Parents need to tell their children the rules for using digital media. Children also have to learn the limit of using digital media so that they won't get addicted to it. One way to prevent this is to create a schedule agreed upon by both parents and children. The schedule made must be adhered to by children, but it is flexible if there are changes in children's activities. 
Limitation and knowledge about digital media are used to prevent negative impacts that may occur. The negative impact of using digital media must be communicated to children so that children have awareness and alertness.

Effective communication between parents and children aims to make children feel safer and more comfortable in using digital media.

\section{References}

Arnus, S. H. (2015) 'Computer Mediated Communication (CMC), Pola Baru Berkomunikasi', Al-Munzir, 8(2), pp. 275-289. Available at: https://ejournal. iainkendari.ac.id/index.php/al-munzir/ article/view/744/680.

Balya, T., Pratiwi, S. and Prabudi, R. (2018) 'Literasi Media Digital Pada Penggunaan Gadget', Jurnal Simbolika: Research and Learning in Communication Study, 4(2), pp. 173-187. doi: dx.doi.org/10.31289/ simbollika.v4i2.1896.

Deveci, T. and Ayish, N. (2018) 'Personal responsibility and interpersonal communication in a project-based learning environment', International Journal of Social Sciences and Education Research, 4(1), pp. 1-17. doi: 10.24289/ ijsser. 331780 .

DeVito, J. A. (2013) Interpersonal communication. 13th ed, Pearson Education, Inc. 13th ed.

Dewi, L., Yani, A. and Suhardini, A. D. (2015) 'Model Pendidikan Karakter dan Kewirausahaan Berbasis Etnopedagogis di Sekolah Dasar Kampung Cikondang', MIMBAR, Jurnal Sosial dan Pembangunan, 31(2), p. 399. doi: 10.29313/mimbar. v31i2.1480.

Halim, H. and Azizan, F. L. (2017) 'Examining Malaysian leader characteristics in a manager-subordinate relationship', Jurnal Komunikasi: Malaysian Journal of Communication, 33(3), pp. 214-230. doi: 10.17576/JKMJC-2017-3303-13.

Juditha, C. (2019) 'Penggunaan Media Digital Dan Partisipasi Politik Generasi Milenial', Jurnal Penelitian Komunikasi dan Opini Publik, 22(2), pp. 91-105. doi: http:// dx.doi.org/10.33299/jpkop.22.2.1628.

Junida, D. S. (2019) 'Kecanduan Online Anak Usia Dini', Walasuji : Jurnal Sejarah dan Budaya, 10(1), pp. 57-68. doi: 10.36869/ wjsb.v10i1.39.

Kurniasih, E. (2019) 'Media digital pada anak usia dini', Jurnal Kreatif: Jurnal Kependidikan Dasar, 9(2), pp. 87-91. Available at: https://journal.unnes.ac.id/ nju/index.php/kreatif/article/view/KR-11.

Muhasim, M. (2017) 'Pengaruh Tehnologi Digital terhadap Motivasi Belajar Peserta Didik', Palapa, 5(2), pp. 53-77. doi: 10.36088/palapa.v5i2.46.

Mulyana, D. (2001) Metodologi Penelitian Kualitatif: Paradigma Baru IImu Komunikasi dan IImu Sosial Lainnya, Bandung: PT remaja Rosdakarya.

Novrialdy, E. (2019) 'Kecanduan Game Online pada Remaja: Dampak dan Pencegahannya', Buletin Psikologi, 27(2), p. 148. doi: 10.22146/buletinpsikologi.47402.

Nugraha, B. and Akbar, M. F. (2018) 'Instagram Active User Communication Behaviour', 2(2), pp. 95-101.

Nurrizka, A. F. (2016) 'Peran Media Sosial di Era Globalisasi Pada Remaja di Surakarta Suatu Kajian Teoritis dan Praktis Terhadap Remaja dalam Perspektif Perubahan Sosial', Jurnal Analisa Sosiologi, 5(1), pp. 28-37. Available at: https://jurnal.uns. ac.id/jas/article/view/18198/14694.

P.Pontoh, W. (2013) 'PERANAN KOMUNIKASI INTERPERSONAL GURU DALAM MENINGKATKAN PENGETAHUAN ANAK I Pontoh | ACTA DIURNA KOMUNIKASI', "Acta Diurna" Vol I.No.I Th.2013, 1(1), p. 11. Available at: https://ejournal.unsrat. ac.id/index.php/actadiurnakomunikasi/ article/view/974/788.

Pransiska, R. (2013) 'Pemanfaatan IT Sebagai Media dalam Mengenalkan Bahasa Ingris pada Pendidikan Anak Usia Dini', Jurnal IImiah IImu Pendidikan, XIII(2), pp. 107-112.

Pratiwi, N. and Pritanova, N. (2017) 'Pengaruh Literasi Digital Terhadap Psikologis Anak Dan Remaja', Semantik, 6(1), p. 11. doi: 10.22460/semantik.v6i1p11.250.

Putra, R. P. et al. (2018) 'Analisis Brand Equity Perusahaan Melalui Media Sosial (Studi Kasus pada Bagian Media Komunikasi PT. Pos Indonesia Persero)', Idea: Jurnal Humaniora. doi: 10.29313/idea. v0i0.4173.

Rahmania, N. Z. and Pamungkas, I. N. . (2018) 'Komunikasi Interpersonal Komunitas Online Interpersonal Communication in Online Community www.rumahtaaruf. com', Jurnal Manajemen Komunikasi, 3(1), pp. 51-66. Available at: https:// pdfs.semanticscholar.org/1abb/4e95760 5b8846410ddb9c5b2d554e1ab6180.pdf.

Rahmawan, D., Mahameruaji, J. N. and Janitra, P. A. (2020) 'Strategi aktivisme digital 
di Indonesia: aksesibilitas, visibilitas, popularitas dan ekosistem aktivisme', Jurnal Manajemen Komunikasi, 4(2), p. 123. doi: $10.24198 / j m k . v 4 i 2.26522$.

Saraih, U. N. et al. (2019) 'Understanding the effects of interpersonal communication and task design on job performance among employees in the manufacturing company', Humanities and Social Sciences Reviews, 7(5), pp. 448-453. doi: 10.18510/ hssr.2019.7550.

Setyaningsih, R. et al. (2019) 'Model Penguatan Nilai-Nilai Spiritual Dalam E-Learning Melalui Standar Literasi Media Pendidikan Online', Mediator: Jurnal Komunikasi, 12(1), pp. 27-34. doi: 10.29313/mediator.v12i1.4367.

Triwardhani, I. J. et al. (2020) 'Strategi Guru dalam membangun komunikasi dengan Orang Tua Siswa di Sekolah', Jurnal Kajian Komunikasi, 8(1), p. 99. doi: 10.24198/ jkk.v8i1.23620.

Triwardhani, I. J. and Chaerowati, D. L. (2019) 'Interpersonal communication among parents and children in fishermen village in cirebon Indonesia', Jurnal Komunikasi: Malaysian Journal of Communication, 35(2), pp. 277-292. doi: 10.17576/ JKMJC-2019-3502-17.

Triwardhani, I. J. and Gartanti, W. T. (2018) 'Supportive Communication In Developing
Housewife's Entrepreneurial Of HomeBased Industry', MIMBAR : Jurnal Sosial dan Pembangunan, 34(1), pp. 61-71. doi: 10.29313/mimbar.v34i1.3107.

Triwardhani, I. J., Trigartanti, W. and Putra, R. P. (2020) 'Study of communication ethnography for entrepreneurship culture in the interpersonal relations of teachers and students', Jurnal Komunikasi: Malaysian Journal of Communication, 36(1), pp. 109-123. doi: 10.17576/ JKMJC-2020-3601-07.

Yin, R. K. (2015) Studi Kasus Desain \& Metode, PT Raja Grafindo Persada. Bandung.

Yohana, N. et al. (2018) 'Communication Model Of Siak Children's Forum Cohesiveness In Actualizing Siak Child-Friendly City', MIMBAR : Jurnal Sosial dan Pembangunan, 34(1), pp. 138-146. doi: 10.29313/ mimbar.v34i1.3222.

Yu, F. L. T. (2009) 'A dynamic model of the entrepreneurial process: A human agency perspective', International Journal of Innovation and Learning. doi: 10.1504/ IJIL. 2009.023292.

Yuniati, Y., Yuningsih, A. and Nurahmawati, N. (2015) 'Konsep Diri Remaja dalam Komunikasi Sosial melalui "Smartphone"', MIMBAR, Jurnal Sosial dan Pembangunan, 31(2), p. 439. doi: 10.29313/mimbar. v31i2.1552. 